\title{
Between "Us" and "Them": Political Subjectivities in the Shadows of the 2018 Brazilian Election
}

Charles Klein

Portland State University, Department of Anthropology |

Portland, Oregon, United States | chklein@pdx.edu |

https://orcid.org/0000-0001-9621-7172

\author{
Alessandra Tavares \\ Universidade de São Paulo, Faculdade de Filosofia, Letras e Ciências \\ Humanas, Programa de Pós-Craduação em Antropologia Social \\ São Paulo, SP, Brazil | adra.tavares@gmail.com | \\ https://orcid.org/0000-0002-8584-4717
}

Dol

http://dx.doi.org/10.11606/ 2179-0892.ra.2020.171482

\section{Milena Mateuzi Carmo}

Universidade de São Paulo, Faculdade de Filosofia, Letras e Ciências

Humanas, Programa de Pós-Craduação em Antropologia Social |

São Paulo, SP, Brazil |mmateuzi@gmail.com |

https://orcid.org/0000-0002-1716-0233

This article examines political subjectivities, community engagements and voting practices among residents of São Paulo's Zona Sul peripheries in the three years preceding Brazil's 2018 presidential election. Building on a 398-person household survey, 46 in-depth interviews, and extensive participation observation over the course of a fouryear study, we argue that although most residents of our study communities across the political spectrum are disenchanted with institutional politics, many maintain political engagement through their everyday lives, including activism centered on intersectional identities and state-sponsored violence/genocide. Our discussion combines statistical analysis and auto-ethnographic inflected vignettes and is in dialogue with two common themes present in recent analyses of the Brazilian political landscape: the role of urban periphery voters in the election of Bolsonaro, and the complex connections between moralities and political subjectivities. In conclusion, we reflect on opportunities and challenges for progressive political engagement in the (post) Bolsonaro era.

Entre "nós" e "eles":

subjetividades políticas nas sombras das eleições brasileiras de 2018

RESUMo O artigo examina subjetividades políticas, engajamento e voto entre moradores da periferia da zona sul de São Paulo, nos três anos que antecederam a eleição presidencial de 2018. Com base em pesquisa domiciliar com 398 pessoas, 46 entrevistas em profundidade e uma extensa observação participante por quatro anos, argumentamos que, embora a maioria dos residentes dessa região estejam desencantados com a política institucional, muitos mantém um engajamento político no cotidiano, incluindo ativismo identitário e lutas contra a violência protagonizada pelo Estado. Nossa discussão combina análise estatística e vinhetas autoetnográficas e está em diálogo com dois temas comuns presentes em análises recentes do cenário político brasileiro: o papel dos eleitores da periferia na eleição de Bolsonaro e as complexas conexões entre moralidades e subjetividades políticas. Concluindo, refletimos sobre os desafios para o engajamento político progressista na era (pós) Bolsonaro.
Political

Subjectivities, Urban

Peripheries, Race Relations, Intersectionality, Social Markers of Difference, Moralities, 2018 Election. 


\section{INTRODUCTION}

Since the election of Jair Bolsonaro as Brazil's president on October 28, 2018, social scientists, political pundits and journalists have offered a barrage of explanations for a result that seemed unimaginable only a few months earlier. For many, Bolsonaro's victory represents the latest in a growing wave of far right, neo-populism across the globe (Estadão Conteúdo, 2018; Estadão Conteúdo, 2019; Mota, 2020). Others see the election as not so much an affirmation of Bolsonarism, but the implosion of Brazil's mainstream center-right political parties and the nail in the coffin to a well-orchestrated anti-Partido dos Trabalhadores/PT (Workers Party) movement (Almeida, 2019). Many commentators, including the authors of this article, further wonder why so many "previously poor" (Klein, Junge, \& Mitchell, 2018), working class, and lower middle class Brazilians voted for a candidate whose interests would appear to align more closely with elite and upper middle class Brazilians (Carta Capital, 2018). Or, turning this question on its head, why did so many previously poor Brazilians stop supporting the PT, whose policies played a significant role in improving their material conditions and creating new life possibilities?

In this article, we focus our attention on voting practices, political subjectivities, and community engagements among the previously poor in São Paulo's Zona Sul peripheries in the three years preceding the 2018 presidential election'. Our analysis centers on data from the São Paulo site (Project MOVI) of a four-year collaborative study on socioeconomic mobility and class subjectivities among the previously poor in São Paulo, Rio de Janeiro and Recife ${ }^{2}$. We begin with an overview of the Zona Sul. Next, we present quantitative findings on political attitudes, voting patterns and community/political engagement in our four study communities, and highlight variation across sociodemographic categories. We then use a series of auto-ethnographic inflected vignettes to explore political discourse and practice in action, before concluding with a brief consideration of what these data suggest regarding the future of Brazilian politics and urban-based political movements.

Our discussion is structured in dialogue with two themes that are present in many analyses of the 2018 election. The first is the extent to which urban periphery voters bear responsibility for Bolsonaro's election. Our project data and electoral results reveal a complicated picture, with lower support for Bolsonaro in the Zona Sul than in other regions of the city, sizable numbers of blank and null ballots, and high levels of disenchantment with the PT. We believe these findings reflect the alienation of many voters from traditional political parties and institutional forms of politics, but not necessarily political disengagement or a widespread entrenchment of extreme-right political views, as we will explore in more detail below. The second theme centers on the interconnections between moralities and political subjectivities in São Paulo urban peripheries. If, as many authors have shown, there has been

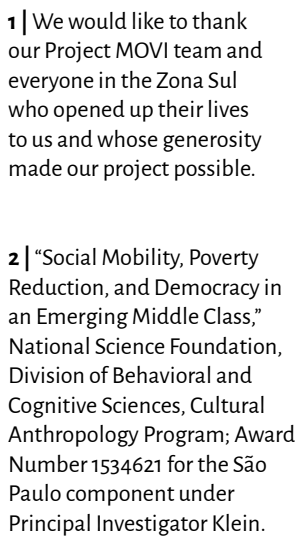


an intensification of "conservative" morality in Brazil in urban periphery communities in recent years (Feltran, 2017; Pinheiro-Machado, 2016), our data demonstrate that many Zona Sul progressive movements centered on race, gender, sexuality, and anti-violence/anti-genocide are similarly expressed in moral terms (Moutinho, 2012, 2014), though a morality quite different than Bolsonarism and other forms of social and political conservatism. Our three sets of ethnographic vignettes explore how São Paulo's peripheries are spaces of intense political and moral conflict that produce both individual subjectivities and the social topography of urban peripheries (Lefebvre, 1991). Our analysis is guided by an "anthropology of becoming" framework that recognizes that people "belong simultaneously to multiple systems that themselves are made up of people, things, and forces with varying degrees of agentive capacity" and "inhabit multiple temporalities at once" (Biehl \& Locke, 2017:5-6). In examining these unresolved and opened-ended processes, we seek to expose factures, or to use Tsing's (2011) terminology, zones of friction, through which urban periphery negotiate the uneven terrain of Brazil's sociopolitical landscapes, and, for some, develop new forms of progressive political engagement.

\section{Methods}

In 2015, the United States' National Science Foundation awarded co-author Klein and two other North American anthropologists a multi-year collaborative grant to examine "Social Mobility, Poverty Reduction, and Democracy in an Emerging Middle Class" in three Brazilian cities-Recife (Benjamin Junge), Rio de Janeiro (Sean Mitchell), and São Paulo (Klein). As is evident in our original project title, when we conceived the study in 2013, Brazil was in the midst of an extended period of economic growth and international acclaim as one of the BRICS economies. By the time we began data collection in July 2016, the country was, in stark contrast, experiencing a severe recession and significant political upheaval. These developments caused us to shift our conceptual framework away from the "new middle class" per se to broader questions of lifeways, economic precarity, and political subjectivities among popular class Brazilians.

Our three-city project used a mixed-methods, ethnographic-grounded approach based in neighborhoods that experienced significant socioeconomic change over the past 15 years (Klein, Junge, \& Mitchell, 2018). Building on PI Klein's prior research experience, the São Paulo site decided to focus on four neighborhoods in the Zona Sul peripheries - Jardim Nakamura/Jardim Ângela, Parque Regina/ Campo Limpo, Parque Santo Antônio/Jardim São Luis, and Grajaú. After assembling and training a 15-person research team, from July to September 2016 we applied a systematic cluster sampling methodology ${ }^{3}$ to implement a quantitative household survey in these four communities. Our approximately 45-minute long instrument

3| For each of our four São Paulo research sites, we used census data to identify ten contiguous census tracts that had experienced socioeconomic mobility during the PT years. We then randomly selected streets within each census tract and approached every fifth house to identify adult respondents to complete the survey, which we administered via a tablet computer. We recruited participants at different times (i.e., weekdays from late morning to early afternoon, weekdays from late afternoon to early evening, and weekends) to capture the broadest possible sample. 
addressed respondents' household characteristics; work history, sources of income, and consumption patterns; household educational trajectories; leisure activities and travel; class subjectivities and experiences of socioeconomic mobility; political engagement; and opinions on contemporary political issues and the quality of life in their neighborhoods. During the second year of the project (July - November 2017), co-authors Carmo and Klein and a third team member conducted in-depth, semi-structured interviews with 41 individuals identified through snowball sampling building on our insertion in our project communities, with Klein conducting an additional five interviews in project year three (August 2018). These conversations ranged from 35 minutes to two hours and addressed household composition; everyday routine and life accomplishments; neighborhood characteristics, class subjectivities and socioeconomic mobility; political opinions and political/community engagement; aspirations for the future; and a mapping activity to identify urban mobility patterns. Throughout the project, Carmo and Klein also conducted extensive participant observation, with particular emphasis on examining interlocutors' social networks, interviews with community activists, and two photo voice focus groups (one with residents of Capão Redondo, and one with members of our research team) in which participants discussed their own digital images of social exclusion and inclusion in São Paulo.

It is important to highlight that nearly all of our São Paulo research team are from the Zona Sul and have similar socioeconomic profiles (i.e. Class $C$ to Class $D$, with a few in Class B3) and life experiences to those of our broader study population. In addition, all have histories of political engagement in the Zona Sul, including participating in Black, Black feminist, anti-violence, neighborhood, environmental, and youth empowerment collectives and social movements. We recognize that the co-authors' personal characteristics - two graduate students at the Universidade de São Paulo, one an Afro-descendant feminist activist from Jardim Nakamura, the other a white, working-class social justice activist from greater São Paulo, and a gay, applied anthropology professor raised in suburban southern California - no doubt shaped our ethnographic insertions and interactions with our interlocutors. We embrace these distinct perspectives and believe our collaborative, auto-ethnographic approach (Ulysse, 2007) provides insights that would not be possible through a single researcher study.

\section{THE ZONA SUL AND OUR STUDY COMMUNITIES}

São Paulo's Zona Sul ${ }^{4}$ peripheries are home to more than 1.9 million individuals and make up nearly $40 \%$ of the city's physical space. As an extensive literature by critical urban theorists demonstrates (Bonduki \& Rolnik, 1982; Kowarick, 2000; Kowarick \& Frúgoli, Jr., 2016; Rolnik, 2011), São Paulo's spatial expansion has occurred in an

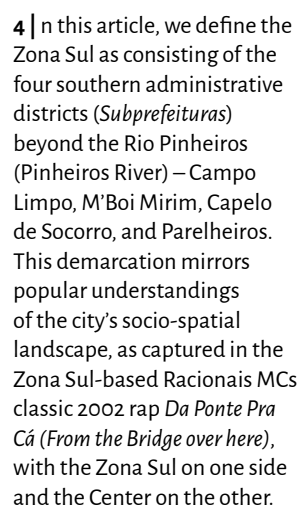


uneven manner in which wealth has concentrated in central regions with modernist architecture, high levels of infrastructure and mostly high-density residential areas, and concentric rings of increasingly poorer neighborhoods surrounding this still-expanding center. In these on-going urban transformations, the Zona Sul is perhaps the city's most dynamic and heterogeneous region, with neighborhoods ranging from luxury condominium complexes (e.g. Vila Andrade), favelas and occupations in the region's outer zones, and significant - if increasingly economically precarious - lower middle and working class populations in its more inner regions (Klein, 2019; Magnani, 1998; Marques, 2014). The Zona Sul peripheries also have among the highest levels of social vulnerability in the city (CEM, n.d.), with one-third of households living below the poverty line. But at ground level, Zona Sul neighborhoods exhibit marked internal variation, as can be seen in our study communities. In each, pronounced socioeconomic difference is frequently visible on any given block, with some houses larger than others, condominiums next to self-constructed homes, and favelas alongside consolidated areas with high levels of infrastructure.

Another central characteristic of the Zona Sul is its concertation of Afrodescendant Brazilians. According to 2010 census data, pretas and pardas 5 represent $56 \%$ of the population of the M'Boi Mirim district (which includes our Jardim São Luis and Jardim Nakamura project neighborhoods), and 49\% in the Campo Limpo district (which includes our Parque Regina project neighborhood), making these

5| The Brazilian census has five official racial/color categories: preta (black), parda (brown/ mixed Black and white), branca (white), indigena (indigenous), e amerela (yellow/Asian). respectively the second and ninth most Afro-Brazilian of São Paulo's 32 administrative districts (Prefeitura Municipal de São Paulo, 2018). In contrast, only $8 \%$ of the population in the nearby yet "other side of the bridge" Vila Mariana district is preta or parda. These data highlight São Paulo's marked racial segregation. During the 1990s, three Zona Sul districts - Capão Redondo, Jardim Ângela, and Jardim São Luis — also received the moniker "the triangle of death," and as community residents still point out today, the United Nations once designated the region the most violent in the world. And after a decrease in homicides in the 2000 and early 2010 s, there has been a significant increase in murder rates in recent years, with an estimated $25 \%$ of the killings being committed by the military police $(\mathrm{G} 1,2019)$.

Like other São Paulo urban peripheries, our project communities have long histories of political organization around the conditions of everyday life (Holston, 2009; Silva, 2017). These social movements have complex and shifting patterns of interconnection with churches, non-governmental organizations, political parties, and the State. During the past decade, there has also been the emergence of a new wave of political organizing through collectives (coletivos) focused on intersectional identities. For example, Grajaú's Cia Teatro de Humbalada modified the social landscape of the region through bringing together "women, fags (bichas), monsters, savages (povos da mata), mothers and Blacks doing theater" in a "center (ponto) of cultural resistance in the periphery" (Cia Humbalada de Teatro, 2017). Such articulation 
of and mobilization around gender, race and sexuality subjectivities in the Zona Sul additionally occurs through saraus (e.g., the renowned Cooperifa in Jardim São Luis) and thriving hip hop and graffiti movements (Bertelli \& Feltran, 2017; Caldeira, 2012; Pardue, 2010; Vaz, 2008). Each of these movements, in its own way, uses artistic production to denounce the harsh conditions of life in the urban peripheries, reinforce positive periphery-grounded identities, and support new political subjectivities and practices at the margins of political parties, electoral politics, and governmental institutions (Bertelli \& Feltran, 2017; Carmo, 2017; D’Andrea, 2013; Klein, 2019).

\section{POLITICAL PRACTICES AND ATTITUDES IN THE ZONA SUL:} FINDINGS FROM THE 2016 PROJECT MOVI HOUSEHOLD SURVEY

During the 2018 presidential election, Jair Bolsonaro solidly defeated former São Paulo mayor and PT candidate Fernando Haddad in both the first round (46.0\% to $29.3 \%$ ) and the October runoff (55.1\% to $44.9 \%$ ) (G1 2018). Haddad fared particularly poorly in the city of São Paulo, where he received only $19.7 \%$ of votes in the first round and $39 \%$ in the runoff. However, a closer look at election results in the Zona Sul reveal less support for Bolsonaro than in the city as a whole. In first round voting, Bolsonaro did not receive more than $40 \%$ in any of the four electoral districts (Campo Limpo, Jardim São Luis, Piraporinha, and Crajaú) in which our project neighborhoods are situated. And while first round support for Haddad in these districts only ranged from $25 \%$ in Campo Limpo to $32 \%$ in Grajaú, another $13 \%$ to $15 \%$ in each district voted for Ciro Comes, suggesting that a sizable subset of the Zona Sul periphery may have center-left/left leanings. Then, in the runoff, two of our project electoral districts, Campo Limpo and Jardim São Luis, narrowly supported Bolsonaro (53.2\% to $46.8 \%$ and $51.6 \%$ to $48.4 \%$, respectively), while Piraporinha and Grajaú went strongly for Haddad (57.4\% to $42.6 \%$ and $56.9 \%$ to $43.1 \%$, respectively), with approximately $16 \%$ turning in blank or null ballots across the four districts. In this section, we present findings from our 2016 quantitative household survey to situate our ethnographic vignettes and provide a window into the complex political subjectivities at play in Bolsonaro's election.

\section{The Sample}

398 respondents completed our survey instrument over the period July-September, 2016. Respondents ranged in age from 18 to 88 (mean $=41.3$ ) with $54.7 \%$ female, $45.0 \%$ male, and .3\% transgender. Using the five Brazilian census race/categories, $41.6 \%$ of the sample self-identified as parda/brown (41.6\%), 30.2\%, branca/white) (30.2\%) and preta/black (26.5\%). In terms of education, $51.1 \%$ had not completed high school, $35.2 \%$ were high school graduates, and $14.1 \%$ had some college education. Fifty-eight 
percent of respondents had worked in the past 30 days, with $42.7 \%$ employed in the private sector, $48.9 \%$ self-employed, autonomous or small businesspeople, and $6.1 \%$ public sector employees. Average monthly household income ranged from o to $\mathrm{R} \$ 13,000$ (mean $=\mathrm{R} \$ 2,807$, median $=\mathrm{R} \$ 2,450$ ), with "Class C" (53.1\%), "working class" (45.6\%), and "Class D" (31\%) the most common class self-identification categories ${ }^{6}$. Regarding religious affiliation, 53.4\% described themselves as Catholic, and 29.7\% evangelical (17.2\% Pentecostal and $12.5 \%$ non-Pentecostal). Most respondents also regularly use social media (75\% were on WhatsApp in the past 30 days, and $64 \%$ on Facebook), and $39 \%$ had a member of their household who had traveled domestically by airplane since 2003 .

\section{Political Attitudes and Practice}

Our survey instrument included sections addressing respondent's political attitudes and practice, including Likert-scale items on overall interest in politics (1 question), degree of conflict in society (6 questions), the Brazilian political system and PT governance (10 questions), gender relations (9 questions), race relations (6 questions), and opinions on 13 contemporary social movements ${ }^{7}$, as well as open- and closed-ended questions on engagement with community/ political organizations, voting in the 2014 presidential election, and participation in street protests since 2013. Our goal in presenting an overview of these data is not to develop or support typologies of "the periphery political subjectivity" or subsets thereof, but rather to draw attention to the breadth and complexities of the Zona Sul political landscape.

Our sample as a whole demonstrated low levels of engagement with institutionalized forms of politics. In response to the question "to what extent are you interested in political topics today", the mean response on a 1 to 5 scale ( 1 = "no interest at all" and $5=$ "a great deal of interest) was 1.8 , with interest in politics increasing with education level (less than high school education $=1.64$, high school education $=2.06$, some college $=2.5, p=001$ ). Less than $1 \%$ of respondents reported participation in a political party, institution council, or labor union in the past 12 months (the highest level of community/political engagement was with "religious institutions" at 4.2\%). On the other hand, $9 \%$ reported participating in a political demonstration since 2013. This alienation from institutional politics was mirrored in consecutive 1 to 5 Likert scale questions on whether respondents felt represented by the Lula, Dilma and Temer administrations, with participants moving from a neutral assessment (2.98) on the Lula administrations to 2.38 for the Dilma-led PT governments to only 1.71 for the then governing center-right Temer administration. Along a similar vein, respondents were neutral (3.00) on whether "the PT improved the lives of people like you" and only $13 \%$ identified the PT as a political party that they "supported or

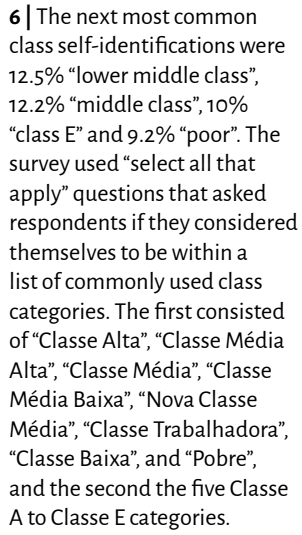

7| Movimento Ambientalista/ Verde, Movimento Brasil Livre, Movimento Feminista, Movimento Estudantil, Movimento Evangélico, Movimento Gay/LGBTQ Movimento Negro, Movimento Passe Livre, Movimento Sem Terra, Movimento Vem pra Rua, Movimentos de Familiares de Vitimas da Violência do Estado Movimento de Moradia, and

the Movimento de Favela. 
sympathized with." And reflecting a growing public discourse on corruption during this period, when asked to identify, from a list of 15 potential problems ${ }^{8}$, the three most critical issues faced in Brazil, $45.9 \%$ of respondents identified corruption as the most critical problem, followed distantly by unemployment at $14.9 \%$ and public security and violence at $7.2 \%$.

An interesting window into understanding the 2018 president election results is the 2014 presidential runoff between Dilma Rousseff and the center-right candidate Aécio Neves. Our sample voted $37.8 \%$ for Rousseff and $21.6 \%$ for Neves ${ }^{9}$, with support for Rousseff highest in Grajaú at 51\%, and in the low to mid-30\% range in the other three neighborhoods $(p=.056)$. Reflecting the alienation from institutionalized politics described above, a staggering $40.6 \%$ of respondents reporting either a null vote $(15.9 \%)$ or not voting (24.7\%). Statistically significant differences in 2014 presidential election voting included:

- education level $(p=.002)$, with high school graduates reporting more null votes/not voting than non-high school graduates (44.1 v. $37.2 \%$ );

- age $(\mathbf{p}=.000)$, with voters under 30 years old reporting more null votes/not voting (65.0\% v. $31.5 \%)$ and less support for Rousseff (20.0\% v. $44.4 \%)$ than voters over 30 years old;

- race/color $(\mathbf{p}=.009)$, with Black respondents reporting higher levels of support for Rousseff (48.5\% Rousseff to 11.7\% Neves) compared to whites (31.9\% Rousseff v. $27.6 \%$ Neves) and pardas (35.4\% Rousseff to $24.1 \%$ Neves); and

- self-identified "lower middle class" status ( $\mathrm{p}=.051)$, with respondents having higher support for Neves (30.0\% to $20.4 \%$ ) and null/not voting rates $(48.0 \% \mathrm{v}$. $39.5 \%)$ than those who did not self-identify as "lower middle class".

There were no significant differences in voting patterns based on gender, religious affiliation, or income.

Our data further suggest that political subjectivities in the Zona Sul are heterogenous, at times internally contradictory, and not readily reducible to overarching political identities (conservative, Petista ${ }^{10}$, feminist, leftist, Black, evangelical, etc.). Particularly salient for grounding our discussions of intersectional activists in our ethnographic vignettes are the observed differences in social and political attitudes based Partido dos Trabalhadores. on age and race. For example, respondents under 30 years old expressed more meritocratic attitudes than their older counterparts, including being less likely to attribute success to one's race $(3.49$ v. $3.84 ; 1=$ not at all and $5=a$ lot, $p=.026)$ or being born into a family with good connections ( 2.69 v. $3.18, p=.004$ ). Young respondents were also more likely to believe same sex marriage should be permitted (3.58 v. 2.96; $1=$ strongly disagree and $5=$ strongly agree, $p=.01$ ), and less likely to agree with the idea that a woman should follow the will of her father (1.70 v. 2.14, $p=.004)$. Black respondents, in 
turn, reported more favorable assessments (either $4=$ good or $5=$ very good on a 1 to 5 Likert scale) than their white or parda counterparts for the feminist movement ( $42.3 \%$ v. $19.6 \%$ of whites and $19.0 \%$ of pardas, $p=.003)$, the student movement $(54.1 \%$ v. $31.8 \%$ of whites and $34.4 \%$ of pardas, $p=.000$ ); the Black movement ( $53.3 \%$ v. $22.4 \%$ of whites and $33.1 \%$ of pardas, $p=.000$ ), the state violence victims movements ( $44.2 \% \mathrm{v} .23 .4 \%$ of whites and $27.3 \%$ of pardas, $p=.000$ ), the housing movement $(39.2 \% \mathrm{v} .27 .3 \%$ of whites and 22.1 of pardas, $p=.024$ ), and the favela movement (34.8\% v. $18.2 \%$ of whites and $16.9 \%$ of pardas, $p=.025)$. How everyday experiences of race and age shape political subjectivities and practice is a central theme we explore in the remainder of this article.

\section{THREE WINDOWS INTO POLITICAL SUBJECTIVITIES} AND MORAL GRAMMARS IN THE ZONA SUL

Having provided a quantitative snapshot of voting patterns and sociopolitical attitudes in our four project neighborhoods, we now present three sets of auto-ethnographic inflected vignettes (one by each of the article co-authors) to provide a more nuanced understanding of how political subjectivities play out in everyday life, electoral politics, and community-based political engagement. These narratives combine data from participant observation, in-depth interviews, and our three distinct experiences of living and working in the Zona Sul. Uniting these narratives is a focus on how contested moralities and intersectional identities shape individual subjectivities and urban periphery sociopolitical landscapes, processes of productive tension which we believe offer insights into the 2018 election and Brazilians politics today.

\section{Politics in Motion (Klein)}

During the past five years, I have made nearly 100 Uber trips within São Paulo's Zona Sul. As a male North American and anthropologist to boot, I nearly always chat with the Uberistas. Sometimes the dialogue begins when the driver hears my gringo accented "bom dia, tudo bem?" (good morning, how are you?) and says "you're not from here, are you?" I answer "I am from the US - where you do live?" Most respond the Zona Sul, and often one of our Project MOVI neighborhoods. From here we usually move into free-flowing explorations of why I am in the Zona Sul and a series of US versus Brazil comparisons on foods, prices, work opportunities, traffic/infrastructure, and, of course, politics.

During my trips to São Paulo in July-September 2018 and February-March 2019, I increasingly adopted a devil's advocate style to delve more deeply into drivers' - and by extension-working class periphery residents'-diverse political subjectivities. So, in response to the litany on how "Brazilians do not understand politics," I question "Who are these Brazilians? Nearly everyone I talk to says the same thing but does not consider themselves to be politically ignorant." When I hear the "PT is corrupt and 
destroyed the country," I ask "more so than other parties? Might the PT have done something good for Brazil as well?" And when drivers voice the classic "Brazil could be the richest/best country in the world," I ask "Why isn't it? What do you think might be done to change the current situation?"

I will now highlight two conversations I had with Uber drivers in August 2018 to provide a glimpse into some of the prevalent sociopolitical attitudes in the Zona Sul during the first-round presidential campaign. The first one was a 40-minute ride from Campo Limpo to the Universidade de São Paulo (University of Sao Paulo) with Daniel, a 30-some, white male driver. He explained to me that he had always supported the PT, but now did not support anyone or any political party. Daniel continued, "Lula, with his background as a common man/laborer, could have taken Brazil to the next level. But he became corrupt. And how could he be president from jail?" I questioned how he would vote in the coming election, and he said "most likely branco (blank), but I can't be sure until I study the candidates more closely." I asked what he thought of Bolsonaro, and he said "I don't like rigid candidates." We then spent the second half of the ride talking about a Brazilian friend of his who lives in Portugal. I learned that Daniel works as an Uber driver part-time, in addition to his full-time job at a multinational food company to save money (his goal is $R \$ 30,000$ ) to support his dream of making a new life in Europe.

My conversation with Daniel echoes our 2016 household survey and 2017 in-depth interview data: low levels of current support for the PT, if sometimes an enduring yet complicated fondness for Lula; a profound disenchantment with institutional politics; and morally grounded assessments of the precarious state of Brazilian society. In July-August 2018, I began to observe another constellation of political subjectivity that was absent - or at least less clearly articulated - in our earlier research, namely, the framing of Bolsonaro as a morally sound agent of change. This narrative is typified by a ride I took just a few days before my chat with Daniel. My driver, Rodrigo, was a pardo male in his early 30 s who lived in Pernambuco and Paraná before settling in São Paulo. He started our conversation by asking me what I thought about the coming election, and I said "well, it looks like Lula will be in jail and not able to run, and Bolsonaro has support, but l'm not sure if he has enough to win." In response, he aggressively critiqued IBOPE ${ }^{11}$ (a well-respected national polling organization) and election polls more generally, saying "How do they know this? They never talk to me or anyone I know!" I countered with the need for sampling in a metropolitan area of

$\mathbf{1 1}$ | Instituto Brasileiro de Opinião Pública e Estatística - IBOPE (Brazilian Institute of Public Opinion and Statistics). 20 million people, but he simply turned his head and rolled his eyes. I then asked if he supported Bolsonaro, and he said "yes" with the following explanation.

\footnotetext{
"This country is a mess and needs order. We need to clean things up. Today you can do anything without any consequences... Things that need to be changed. Like gay marriage. I have nothing against gay people, but this can't be (não pode)-it's not right-marriage is for the family, children.
} 


\author{
And sex education - I have a six-year-old, and in school they say "penis" - this can't be. And gun control \\ (desarmamento) - this is wrong-ifyou take a class you should be able to have a gun." \\ (Rodrigo, mixed race male, Uber driver, early 30 s)
}

To sum things up, he concluded, "Brazil is not the problem; it is strong. The problem is Brazilians."

Coming back to post-election Brazil in February 2019, I encountered more outspoken Bolsonaro supporters, though none as strident as Rodrigo. I found that pro-Bolsonaro and anti-PT sentiment were intricately and unstably interlinked. This shifting landscape of political subjectivities can be seen in the Alves family, who I know well from our Project MOVI research. As was common during the election, several members of the family stopped speaking to each other after disagreeing about Bolsonaro, and in particular, his racist, sexist and homophobic comments. But post-election, the rifts seemed submerged, if not exactly healed.

Like many families in the periphery, the extended Alves clan includes households who range in income from Class $D$ to lower Class $B$, with most in Class $C$, while Henrique, an in-law, comes from a solidly traditional middleclass family. Having interviewed four family members in August 2018 and spent considerable time with them over the past three years, I have a general sense of their political sentiments, which, with the exception of one progressive community activist, I would categorize as socially liberal, non-religious, apolitical, anti-Lula, and anti-PT. While none explicitly supported Bolsonaro at the time of the interviews, Henrique offered the following assessment of Bolsonaro and what Brazil needs:

\footnotetext{
"This Bolsonaro, he's somebody who says too much. We need someone better, a military person, unfortunately. They are more conservative - unfortunately, this is what we need. No one is taking care of things, people do whatever they want. It's like this-Brazilians need to learn, they need a spanking. Without a spanking, they'll never learn!" (Henrique, white male, entrepreneur, 47 years old)
}

Four months later I spent carnaval at Henrique's rented beach house and had a number of give-and-take political conversations with family members, several of their friends, and other guests at the complex. Our topics ranged from pension "reform" (Henrique and his 27-year-old partner Denise said they would prefer "private investments and retirement plans" to the current governmental system), the January 2019 dam collapse tragedy in Brumadinho, Minas Cerais (Denise's mother said that the firm behind the tragedy and the federal government's responses were shameful, and we all agreed), and the challenges of being a small businessperson in Brazil. On this last point, the hosts and their entrepreneur friends used a meritocratic discourse to describe their experiences in a business environment that they see as combining excessive taxation, regulatory obstacles, and employees who do not 
want to work ("We pay above market wages, yet they do not have a work ethic and describe their work as slavery"). Their identity as morally grounded, hardworking businesspeople is not, however, framed in terms of the traditional gender/sexual politics advocated by Bolsonaro supporters such as my Uber driver Rodrigo. Instead, Denise and Henrique see Bolsonaro as someone who may be able to set Brazil on a better economic course, and who, perhaps most importantly, affirms their status as self-sufficient entrepreneurs who create wealth and jobs. In this moral grammar, the PT functions as a free-floating signifier of the dangers of corruption and social programs (e.g. the Bolsa Família ${ }^{12}$ ) that discourage people from valuing work. And in the end, disrespects hard workers such as themselves.

\section{Window 2: Politics on the Margins (Carmo)}

\begin{abstract}
[In the past] I respected, I liked, and always voted for the PT. My father is a steelworker, a trade unionist. He always supported and voted for Lula, and I always voted for Lula. I wasn't really conscious of what I was doing - he voted for Lula and I voted for Lula. During his re-election, I didn't vote for Lula - I voided my vote because I was already beginning to be disenchanted [with the PT], but I voted for Dilma in her second term. So, you see, the PT was a party I consistently voted for. And then the party began to splinter, and there were new parties on the left, and I voted for them. (....). Now I don't vote for anyone! I've decided if it has to be Lula, or whatever, Bolsonaro, only to save my neck would I vote for Lula. But I don't want to vote for the least bad. Because in the past few elections I have voted for the least bad, and this made me feel awful. (Paula, Afro-Brazilian, 38 years old, July 2017 interview).
\end{abstract}

Paula has lived in Grajaú her entire life. Like many São Paulo periphery youth, she began working as an adolescent (in her case, at 15), first for several large corporations based in the downtown region, and then switching to the public/non-profit social service sector. Since 2010, she has worked as an educadora social ${ }^{13}$ for a governmental child and youth service agency. At the time of this interview, Paula had recently discontinued her college studies in the sociology program at a for-profit private university because she could not afford the monthly tuition bill. She is also the mother of a teenage daughter and a founding member of a Zona Sul cultural activist group whose work has focused on the interconnections between gender, race, sexuality and periphery subjectivities.

Paula's life path is similar to many activists I have worked with since arriving in the Zona Sul in 2011: studying in the public education system for elementary, middle and high school, but enrolling in for-profit, private institutions for college; entering the work force at a young age; being parents of non-adult children; having professional trajectories in non-governmental organizations and governmental social programs; and participating in periphery-based cultural/political groups, in particular, the many collectives (coletivos) that have multiplied rapidly in São Paulo's peripheries in the past decade. Paula connects her activism to the unconscious influence of her
12 | The Bolsa Família (Family Grant) is a federal social welfare program that provides financial aid to low income families on the condition that their children attend school and are vaccinated.

13 | An educadora social (literally "social educator") in Brazil combine the roles of teacher, social worker, and community organizer. 
trade unionist father when she was a child. As a large social science literature has documented, a key feature of the emerging participatory democracy in Brazil's urban peripheries during the 1970s and 1980s in the post-dictatorship abertura (opening) was an interconnection between leftist political parties, labor unions, and social movements (Dagnino, 1994; Kowarick, 2009). However, over the course of the 1990 s and 2000s, many social movements gradually lost their role of militant revindication and instead became incorporated within the state bureaucracy as providers of social programs (Carmo, 2017; Feltran, 2011). Paula and her family are part of these historical processes, although their political trajectories differ - while her father's generation of metalworkers were labor union and PT militants, Paula has experimented with other forms of political engagements that have few if any connections to the PT or other political parties and are characterized by an underlying distrust of conventional political discourse and structures. Most of these collectives are made up of youth and young adults and organize around everyday experiences of intersectionalities, with particular emphasis on denouncing inequalities and state violence.

If Paula and many other collective activists gradually became disillusioned with the PT and created news forms of political engagement, it is important to recognize that some Zona Sul residents ( $13 \%$ of respondents in our 2016 survey) continue to identity with the PT and recognize its role in supporting the economic and social advances of urban periphery communities. As Capão Redondo resident Danilo explained to me, during the time of the PT governance, "people in the periphery had a little more space, a little more awareness." Cynthia, from Capão Redondo, further observes that the PT "gave a little more dignity to the poor." Such appreciation of the PT is less commonly voiced by collective activists, whose political narrative often positions the PT, as representatives of the State, as promoting the genocide of the poor Blacks in the periphery and defending party and state interests over the necessities of periphery residents.

My own personal and professional trajectory in the Zona Sul has provided me the opportunity to observe these transformations firsthand. In 2011, I began working in a longstanding non-governmental organization that develops social projects linked to the human rights of children and youth. In this work, I have accompanied the development of the new forms of political subjectivities, discourses and practices that Paula describes and that were common among many youth and young adult activists I encountered. A key moment in these sociopolitical transformations was the period from 2013 to 2016, when a wave of collectives centered on intersectional identities emerged, including, among many others, Fala Guerreira (Speak Women Warriors!) (Projeto Fala Guerreira!, 2017), Periferia Segue Sangrando (Periphery Continues to Bleed) (Periferia Segue Sangrando, n.d.), and Tamo Vivo (We Are Alive) (Tamo Vivo, n.d.). This blossoming of collectives coincided - and tensely coexisted - with the administration of then São Paulo mayor Fernando Haddad. One of Haddad's key periphery-directed policies in this period was the Plano Juventude 
Viva (Youth Alive Plan) ${ }^{14}$, which focused on ending the killing of youth at a time when youth homicides rates were rapidly rising. These tensions were vividly displayed at planning meetings, public hearings, and project-related events, such as the program inauguration at the $\mathrm{CEU}^{16}$ Casa Blanca in 2013, which included the participation of Haddad and the representatives of many city departments. At the conclusion of the official opening comments, youth from the Tamo Vivo (We are Alive) collective climbed onto the stage, seized the microphone, and recited this poem.

Está quase na hora de partir
Caminho com passos rápidos
Mas cautelosos, né?
Periferia, você sabe
Não se pode vacilar
A chuva fina que cai do céu
O vento frio que bate no meu rosto
Com eles veem a notícia
Que já foram quatro mortos pela polícia
Uns dizem
Estava na hora errada, no lugar errado
Outros dizem
Foi o motoqueiro fantasma, mano
Mas a certeza é
Mais um nas estatísticas
Mais um arquivo fechado
Mais um preto morto
Nessa porra dessa ditadura
Nós aqui, ó
Somos apenas sobreviventes
Do campo de extermínio, tá ligado?

$\begin{array}{ll}\text { It's almost time to leave } & 16 \mid \text { Centro Educacional } \\ \text { I walk fast } & \text { Unificado-CEU (Unified } \\ \text { Educational Center). }\end{array}$

But cautiously, right?

Peripehry, you know

You can't vacillate

The light rain falls from the sky

The cold wind hits my face

With them comes the news

That four were already killed by the police

Some say

They were in the wrong place at the wrong time Others say

It was the ghost biker, brother

But the certainty is

One more statistic

One more closed case

One more Black man dead

In this fucked-up dictatorship

We are here, look

We are only survivors

From the concentration camp, are you listening?

Unificado-CEU (Unified
14 | The Plano Juventude Viva was established in 2012 by the federal Secretaria Nacional de Juventude/SN] (National Youth Secretary), which is linked to the Secretaria-Ceral da Presidência da República (General Secretary of the President of the Republic). Its stated objective was to reduce the social vulnerability of Black youth in order to prevent violent situations (Ministério de Família e dos Direitos Humanos, n.d.) Educational Center).

This daring act not only destabilized formal meeting protocols, but its highlighting the gap between "reality" and the suffering caused by so many murders resulted in a combination of euphoria and discomfort, particularly since the youth was the "target population" of the program. This display of antagonism between the new collectives and the PT stands in stark contrast to the PT's relationship with social movements in the 1970 s and 1980s, when the PT was generally seen as representing popular class interests and aspirations, and demonstrates the shifting political landscape of Zona Sul political activism during the 2010 s.

In making sense of these political transformations and their possible connection to the election of Bolsonaro, it is important to stress that the collective's 
self-conscious positioning outside of institutional politics and state-led initiatives is not grounded within an anti-corruption discourse, but in their everyday experiences with police violence and the representatives of political parties who administer public policies such as the Plano Juventude Viva. What I seek to highlight here is that the positioning of activists who support the goals of similar collectives and grassroots organizations does not represent political alienation. On the contrary, these activists dedicate themselves to political engagement at the level of everyday life and create spaces, discourses and practices that help make sense of a social world profoundly shaped by social inequality, racism, and gender and police violence. Through their political engagements, these activists are not only producing themselves as subjects (Butler, 1997), but are also forging new life possibilities and paths of resistance. These intersectional moralities are based on markers of social difference such as race, gender, sexuality and class (Moutinho, 2012). These categories produce intervals in everyday life, which themselves are reiterated or transformed through these everyday interactions. As a result, examining how politics is (re)produced in the fluxes of everyday life is fundamental to understanding the broader Brazilian political landscape (Feltran, 2017). For example, when collectives place the responsibility for the death of youth on the State and characterize these killings as genocide, they question the idea that "a good criminal is a dead criminal" (bandido bom é bandido morto) as well the naturalization of police violence and punitive law enforcement, corrections and legal systems. Certainly these discourses are most strongly articulated within activist circles, but they also reverberate in neighborhoods through public events such as youth-focused, anti-violence/anti-genocide events throughout the Zona Sul and the Cia Humbalada of Teatro's Grajaú Vem Tomar no Copo carnaval bloco (Klein, 2019) in which Paula participates. And besides such structured events, intersectional activist moralities tensely circulate and impact activists' extended family networks, which are themselves microcosms of the racial, religious, political and moral diversities of the Zona Sul. As a result, although collective-based activists may position themselves outside of - and often, against - the State and institutional politics (including that of the left), in their everyday lives they spread progressive viewpoints well beyond the confines of activist collectives, and in the process, explicitly challenge the growing wave of conservative moralities and politics within their families and neighborhoods.

\section{Window 3: Politics in Everyday Life (Tavares)}

In the month before the election, I overheard arguments everywhere-on the bus, at bars and cafes, on the streets - any place where people come together in São Paulo's urban peripheries. The disputes involved a hardening of social difference - on one side, a conservative, moral rejuvenation political project centered on customs, life 
styles and new subjectivities that need to be controlled, and on the other side, a defense of the PT's project of economic development and expansion of individual and social rights. In these conversations, PT supporters called Haddad "my professor" and invoked the rational language of statistics and public policy to argue for the continuation of PT programs, a dramatic shift from the impassioned and inspiring rhetoric of Lula's 2002 presidential campaign. In contrast, Bolsonaro supporters presented themselves as agents of change and emotionally called for cleaning the political house and defending conservative social morays and the "family." And rather than engage in public policy discussions with Haddad supporters, most Bolsonaristas simply dismissed all PT candidates as corrupt petralhas.

These debates extended into the world of social media, and in Jardim Nakamura, one of our Project MOVI neighborhoods, I observed many of these exchanges firsthand. A neighbor would open her Facebook and share the gossip for everyone - "You know that Fabricio is going to vote for Bolsonaro!" Everyone around herwould stretch their necks to see the screen and, in disbelief, read a post defending Bolsonaro's call for the right of Brazilians to bear arms. A comment ironically countered "you'll be able to spend $R \$ 5,000$ on a gun to defend your $] 6$ (an inexpensive cellular phone)", generating online guffaw emojis and physical laughs from some of the gathered neighbors.

Through such humor-laced interactions, the streets of the Zona Sul experienced a level of political agitation not seen since the candidacy of Paulo Maluf in 1993 and the ongoing political disputes surrounding him during the 1990s. These arguments were often tense, with Bolsonaro supporters speaking in hushed voices, as they saw themselves as being in a threatening territory that historically belonged to the PT, but whose predominance had waned over the years due to a combination of disappointment about Brazil's overall political situation and a gradual decline in support for the party from local community activists. These transformations in the political landscape intensified after the election of Dilma Rousseff, and it was in this context, just two days before the election, that I observed the following interaction.

\section{Scene 1}

It was a late afternoon in Jardim Ibirapuera, and two young Black women were smoking a joint and chatting in an alleyway staircase. One of them, Ana, had straight hair, and the other one, Eluiza, had curly hair in a Black power style, a detail that will become pertinent as the scene evolves. They suddenly heard a voice of an older women, and after a few moments, realized that she was talking to or - more likely - at them. But they did not understand exactly what she was saying, and so, to keep safe and be polite, they put out the joint. And then they understood what she was saying: "What horrible hair. You need to take care of it. How can you go out with hair 
like that! It could only be someone like that."

Both were totally embarrassed, and Ana turned toward Eluiza, whose Black power hair was the subject of the older women's outburst, and they tried to find some way to communicate to her through their eyes and silence. But she did not get the message and continued to weave her barrage of swearing and critiques of Black power hair. Walking past Ana, the older woman continued,

"You need to talk to your friend and take care of this hair. You can't be on the street with hair like that. Hair like that doesn't belong on the streets. She looks like she is one of those women with armpit hair. Cod forbid - that kind votes for the PT!"

And with this final pronouncement, she descended the staircase.

Later that day, I was sitting with Ana and Eluiza at a nearby neighborhood bar, and we reflected on what had happened. I asked, "But what did you do?" and Ana responded,

\footnotetext{
"Nothing. We just watched, paralyzed, without understanding any of it. But, reflecting on what happened, I think I wouldn't have wanted to say anything. This woman was also Black. What could I say to her? And she had the same hair too!" [and which she denies through the use of hair products].
}

It is not possible to make sense of this scene without examining the moral grammar that underlies the reactions of both the two young women and the older women. In reflecting on the production of difference and inequality, Moutinho asks us to consider the mechanisms of power that generate differences between an "us" and a "them"'(Moutinho, 2014). Seen in this light, the older Black woman's reaction to Black power hair demonstrates her understanding of feminist movements and politics at the same time it constructs a "them" in opposition to proper people such as herself. On the other hand, what moral regime(s) and mechanisms of power underlie that reaction of the youth women? Here, we can observe the influence of a growing Zona Sul feminist movement centered on questions of class, race and sisterhood. This movement asserts that even in the face of public discrimination, an "us" can be preserved, one that offers empathy and that opens a crack between the "we" constructed through activism and the "we" of the violent, ambiguous and conflictive world of everyday life.

\section{Scene 2}

The interaction presented in Scene One reminds me of an experience that occurred during our Project MOVI fieldwork in Crajaú. We were looking at our map to decide where to begin implementing our survey. We were three blocks from the train 
station, surrounded by some houses that suggested higher economic status, and others of a more popular class profile. In the language of our research, these were Class $C$ and D families. On that day, seven members of the Projeto MOVI team were in the field. Most of us were Black women, along with one young Black gay man. We all presented ourselves corporeally and aesthetically through popular class cultural motifs, and as we often discussed among ourselves without reaching a resolution, we wondered if our social backgrounds and appearances might affect the responses and/or behavior of the interviewees. The scene that I will recount here involves a situation when one of our researcher's sexuality became evident during survey administration. Of course, sexuality does not always have an obvious corporeal expression, but in this case, Jonas' sexuality was readily evident, as our team member is markedly "effeminate" in his gestures and speech - in popular language, he is a queen (bicha afetada).

On this particular afternoon, Jonas walked toward the first house on our map to see if the resident was interested in participating in our survey. The potential interviewee, an approximately 20-year-old Afro-descendant man, agreed, and a lively and spontaneous conservation began, one with moments of relaxation and affinity, as often happened during our research in all four neighborhoods. As described above, our survey addressed many different levels and dimensions of our respondents' lives, including polemic issues, such as whether they support gay marriage. In response to this question, the interviewee stopped smiling and responded, "I totally disagree. Nothing against you, brother. Everyone can do what they want. But marriage, no, I am against it. But I don't have anything against you." The interview then continued along a similar pattern, generally friendly yet with abrupt moments of awkwardness in which their connection became strained.

When we got together at the end of the day and processed our experiences, we talked about how this interviewee supported the legalization of marijuana, was against male chauvinism, and generally gave very liberal responses to our social attitude questions. Yet, at the same time, he was staunchly against gay marriage and seemed uncomfortable positioning himself alongside another person who was obviously affected by what he thought, although the interviewee did not see his response as constituting any form of discrimination.

In this example, we see how the production of difference in everyday life is connected to mechanisms of power that are themselves continuously in play. To begin with, the interaction of the two men is marked by a shared cultural repertoire and affinities across many domains. The asking and responding to the gay marriage question touches on the difference between "us" that had not fully unfolded until this moment, and produces a "them." That is, in saying "I don't have anything against you, but I am against gay marriage", the interviewee is trying to differentiate between the legitimization of violence and the denial of rights. The fact that he is 
against the social legitimacy of homoaffective relations is not, in his eyes, connected to legitimizing homophobic violence. He also indirectly affirms this distinction by his very agreeing to participate in a survey on such controversial topics and generally behaving in a friendly manner. Yet, his denial of the rights of LCBTQI+ communities is itself a form of homophobic violence, not lethal, but nonetheless, very blunt.

\section{Final Thoughts}

In these everyday disputes on the eve of the second-round voting, we can observe how the 2018 elections drew attention to the supposed dangers posed by youth whose behavioral patterns are popularly described as "having lost respect" (perderam o respeito). This concept brings together a wide range of "morally questionable" activities, including cell phone theft, indiscriminate marijuana use, public expression of lesbian and homoaffective relationships, women showing their breasts during carnival, the growth of trans and travesti identities, new Black aesthetics, feminist political action through posters and public interventions, and above all, new forms of sociability and the negotiation of public space in urban periphery neighborhoods. The growth of support for Bolsonaro is further interconnected with mechanisms of power that react to these new political postures, actors and subjectivities that make the private public and dispute the moral grammar of everyday life. Or, as the older Black woman from Scene One affirms, "there is no place for hair like that."

Anthropologists have consistently demonstrated how humor can function as both a social gesture and a politics of subversion (among others, Douglas, 1977; Coldstein 2003; Pettegrew, 2017). In the context of the politics of everyday life, laughter offers a mechanism for reflecting, critiquing and contesting not only articulated beliefs and disbeliefs, butalso the empty spaces alongside them. As my ethnographic vignettes reveal, the 2018 election unfolded like a sports rivalry in which conversation flowed through jeers, off-color language, and jokes, with humor the thread that enabled the two sides to position themselves within the conflict, and in many cases, avoid more extreme forms of confrontation. I conclude this section by offering two vignettes that highlight how Zona Sul activists use humor as a way to navigate and challenge ongoing experiences of intersectionalities in the context of an always shifting political landscape.

\section{Scene 3}

It was almost election day. We were seated outside at a bar, four women having a beer and sharing our disbelief at how the election might play out. Bete suggested that the election was like an abusive relationship, and we all started laughing. She continued, "he always says he is going to change, be different, and you believe it, but 
the same violent patterns continue. You have a sense of inferiority and that's how it goes." We all laughed, and Vera concluded her thought, "Then you isolate yourself from family and close friends." And we laughed even louder, as only laughter made clear what before had seemed inexplicable.

\section{Scene 4}

More recently, I was with a group of women talking about the abusive relationship of a friend of ours, and we were finding it hard to believe what was happening. Fernanda Gomes, a lesbian activist from the Zona Sul, began to laugh and said, "You all talk about these boys the same what you talk about the PT.'I believed in you, but you did this? You disappointed me, but I continued to believe in you." Laughter took over the room as we recounted our many disappointments with men and the PT. Here is it important to emphasize that while many middle-class Brazilian intellectual continue to strongly defend the PT and social and economic advances that occurred during PT governance, which are uncontestable facts; for activists in the Zona Sul periphery, these advances simultaneously bring up a series of disappointments and negotiations. Among the most vivid is the 2012 image of Lula shaking hands with Paulo Maluf, an ongoing symbol of military repression and corruption among community activists in the Zona Sul peripheries.

\section{CONCLUSION - LIVING IN THE (POST)-BOLSONARO WORLD}

In this article we have highlighted some of the diverse and multifaceted political subjectivities of residents of São Paulo's Zona Sul with the goal of providing insights into the current political scenario in Brazil. Rather than assuming that individuals are simply victims or pawns of large structural forces (e.g., Globo, WhatsApp, consumerism, a well-orchestrated anti-PT movement), we argue thatZona Sul residents have unfinished-and at times internally contradictory - political subjectivities that do not reduce to left/right, pro-PT/pro-Bolsonaro, or pro-PT/anti-PT political identities. Instead, we argue that for many Zona Sul residents, political subjectivities are morally, rather than ideologically, grounded and (re)created through everyday experiences of intersectionalities. These processes can be seen in the lives and political activism of Paula and other collective members who continue to seek new paths of resistance in an increasingly hostile and unsettled political environment. Similarly, Rodrigo, the pro-Bolsonaro Uber driver, is also constructing a new moral grammar and life path, one in which, if we take his words at face value, he "has nothing against gays" yet supports the reassertion of "traditional" moral values. Of course, as Tavares argues in her analysis, such attitudes express a latent homophobia. But perhaps Rodrigo is less homophobic than interested in affirming his own moral worth, which 
he defines partly in terms of conservative social morality yet also, perhaps, in terms of being able to support his family in the manner he would like, a possibility that has become increasingly difficult during an extended recession. At the same time, many Bolsonaro supporters we have talked to, including the Alvez family and the extended familial networks of Carmo and Tavares, like that Bolsonaro says "outrageous" things, but may not think that he will actually follow through on making them a reality.

In attempting to understand the complex political subjectivities of individuals across the ideological spectrum, we do not mean to minimize these dangers posed by the Bolsonaro presidency and the implementation of his policy agenda. Quite the contrary. Instead, we seek to expose zones of friction (Tsing, 2011) that might be conducive to progressive social change and counter a common feeling that we have encountered in our fieldwork, namely that "there is no more "us" (não têm mais nós). We believe the examples of the everyday construction of "us" and "them" we have described are examples of such zones of friction, operating on many difference scales and raising many questions. For example, is the older Black woman who finds Black power hair abhorrent part of the "us" of Black women from the periphery (i.e., mulheres negras periféricas) articulated by Black feminist collectives, in that she has a similar class background, gender and race as collective activists? Or who exactly in the "us" of periphery-based Black movements, one of whose key calls to action is "we are all Black" (somos todos negros), when our quantitative data suggests that many Afro-descendant Brazilians who self-identity as parda have markedly different political attitudes and social positioning than those who self-identity as preta. And what of Rodrigo and our survey respondent's invocation of "I have nothing against gays", which would seem to include gays in the grand "us" of informal sociability, but deny gays the right to the legal recognition of their relationships and confine the expression of homoaffectivity to the confines of the home in order to not offend family morality. And this in a country where more than 40 million children live in female-headed households without a present father (Carasco, 2018).

It is important to note that our survey, interviews, and most of our field work occurred before the election of Bolsonaro. Since then, markedly political polarization continues, particularly over differing views on what roles the State should take in enforcing certain conceptions of morality, guaranteeing civil and human rights, and addressing the social needs of vulnerable individuals and communities. Exactly how the collectives we have presented in this article will respond to the challenges posed by the Bolsonaro administration and neo-populist conservatism is still evolving. One change we observed in the first months of the Bolsonaro era is a growing willingness on the part of some collective activists to work within certain sectors of the State from an explicitly oppositional positioning. For example, a member of a Zona Sul feminist collective became a staff person for a São Paulo state representative who is a trans 
Black women, while Monica Seixas was elected a São Paulo state representative as the official candidate for a nine-person group of collective activists.

And who would have predicated the arrival of COVID-19 in São Paulo in February 2020? In thinking about contemporary social movements and political organizing in the Zona Sul during this terrifying conjecture, we believe capoeira offers an excellent metaphor. Over the past 18 months, many collectives have slowed their activities and taken the time to reflect on the cultural and political interventions they might make in a still shifting political landscape, and many groups have disarticulated as a result of internal conflict. The return, the silence, the step behind-capoeira helps us see that this pause may offer greater understanding of the current situation, a better entry point, a step back before a counter strike. The waiting and silence of the capoeirista does not signify giving up, but on the contrary, but the pursuit of the wisdom needed to continue the fight.

As São Paulo experiences the ravages of the COVID-19 pandemic, we now see that rather than organizing around the experiences of intersectionalities and state violence, a majority of collective activists are now organizing around distributing basic necessities, such as food, gas, and economic resources, for periphery families who are losing their jobs or unable to work. Many of these families were already socially vulnerable before the arrival of COVID-19, and their precarity is further aggravated by the pandemic. Yet, laughter accompanies this shared social catastrophe. As a Zona Sul activist comments to one of us, "I have never eaten so well as at this time of the pandemic. They send us the donations they receive from closed stores. Who would have imagined that we would now have highest quality diapers and chocolates!" And everyone laughed.

Charles H. Klein is an applied urban anthropologist and Associate Professor in the Department of Anthropology at Portland State University in the United States. His Brazilian research is based in São Paulo and urban periphery communities, cultural political movements, emerging classidentities, and first-generation collegestudents. His US research agenda centers on developing technologically-delivered sexual health promotion programs for racially diverse LCBTQ+ communities. He has recent publications in City \& Society, Economic Anthropology, Teaching Anthropology, AIDS Education and Prevention, Health Promotion Practice, JMIR Public Health Surveillance, and AIDS and Behavior. This project was supported through a National Science Foundation, Division of Behavioral and Cognitive Sciences, Cultural Anthropology Program Award (\#153462) and a Faculty Enhancement Crant from Portland State University. 
Milena Mateuzi Carmo is a PhD student in the Postgraduate Program in Social Anthropology, College of Philosophy, Arts and Human Sciences (FFLCH) at the Universidade de São Paulo (University of São Paulo) and a CAPES (Coordenação de Aperfeiçoamento de Pessoal de Nível Superior) Scholar. She obtained her Bachelor Degree in Social Science in 2005, and a Master's Degree in Social Anthropology in 2016, from the same institution. She has extensive work experience in developing and implementing social programs in the governmental and non-governmental sector. Her current research focuses on youth, violence, social policies, and social inequality.

Alessandra Tavares is a Masters' degree student in the Postgraduate Program in Social Anthropology, College of Philosophy, Arts and Human Sciences (FFLCH) at the Universidade de São Paulo (University of São Paulo) and a CAPES (Coordenação de Aperfeiçoamento de Pessoal de Nível Superior) Scholar. She obtained her Bachelor degree in Social Science at Pontifícia Universidade Católica de São Paulo - PUC-SP (Pontifical Catholic University of São Paulo) and a specialization in Cultural Project Managementand EventOrganization from the Centro de Estudos Latino-Americanos sobre Cultura eComunicação-CELACC (Center for Latin-American Studies on Culture and Communication) at the University of São Paulo. Her professional work focuses on educational policy and restorative justice, and she is active in various social movement in the Zona Sul of São Paulo.

\section{AUTHORS' CONTRIBUITION:}

All three authors contributed equally to the writing of this article and collected parts of the data cited in the article.

\section{BIBLIOGRAPHICAL REFERENCES}

ALMEIDA, Ronaldo de. 2019. "Bolsonaro presidente: conservadorismo, evangelismo e a crise brasileira". Novos Estudos CEBRAP, v.38, n.1: 185-213.

BERTELLI, Giordano Barbin \& Feltran, Gabriel. 2017. Vozes à margem: Periferias, estética e política. São Carlos, SP: Editora da Universidade de São Carlos.
BIEHL, João \& Locke, Peter. 2017. Unfinished: The Anthropology of Becoming. Durham; London: Duke University Press.

BONDUKI, Nabil \& Rolnik, Raquel. 1982. "Periferia da Grande São Paulo: Reprodução do espaço como expediente de reprodução da força de trabalho". In: $A$ produção capitalista da casa (e da cidade) do Brasil industrial. Alfa-Ômega, pp. 117-154. 
BUTLER, Judith. 1997. The Psychic Life of Power: Theories in Subjection. Stanford, Calif.: Stanford University Press.

CALDEIRA, Teresa. 2012. "Imprinting and moving around: New visibilities and configurations of public space in Sao Paulo". Public Culture, v.24, n.(2)(67): 385-419. https://doi.org/10.1215/08992363-1535543

CARASCO, Daniela. 2018. "Vivemos uma epidemia social de abandono paterno". Retrieved August 4, 2019, fromhttps://www.uol.com.br/universa/ noticias/redacao/2018/04/10/vivemosuma-epidemia-social-de-abandonopaterno-diz-promotor.htm

CARMO, Milena Mateuzi. 2017. Margem adentro: Políticas sociais, sujeitos e resistências na zona sul de São Paulo. São Paulo, Masters, Universidade de São Paulo.

CARTA CAPITAL. 2018. As pessoas não sabem que votam contra si ao votarem em Bolsonaro. Retrieved June 15, 2020 from https://www.cartacapital.com.br/ economia/as-pessoas-nao-sabem-quevotam-contra-si-ao-votarem-em-bolsonaro/

CEM. (n.d.). Mapa da Vulnerabilidade Social: Centro de Estudos da Metrópole. Retrieved December 22, 2018, from http:// web.fflch.usp.br/centrodametropole/584

CIA HUMALADA DE TEATRO. 2017. Grajaú Conta Dandaras, Grajaú Conta Zumbi.

DAGNINO, Evelina. 1994. "Os movimentos sociais e a emergênica de uma nova noção de cidadania". In: Anos 90s: Política e Sociedade no Brazil. São Paulo: Brasiliense, pp. 103-115.

D’ANDREA, Tiaraju Pablo. 2013.

A formação dos sujeitos periféricos:

Cultura e política na periferia de São Paulo; Universidade de São Paulo, São Paulo, SP.
DOUGLAS, M. 1971. "Do dogs laugh?" Journal of Psychosomatic Research, v.15: 387-390.

ESTADÃO CONTEÚDO. 2018. Nenhuma força política deterá a extrema-direita no Brasil, diz historiador. Retrieved June 15, 2020, from https://exame.com/brasil/ nenhuma-forca-politica-detera-a-extremadireita-no-brasil-diz-historiador/ 2019. Cientista político Yascha Mounk teme "início de era populista." Retrieved June 15, 2020, from https://exame.com/mundo/ cientista-politico-teme-inicio-de-era-populista/

FELTRAN, Gabriel de Santis. 2011. Fronteiras de tensão: Política e violência nas periferias de São Paulo. São Paulo: Editora Unesp. . 2018. "A categoria com

intervalo: A diferença entre essência e desconstrução". Cadernos Pagu, v.51.

G1. 2018. Eleições 2018 Retrieved on November 15, 2019. from https://g1.globo. com/politica/eleicoes/2018/apuracao/brasil/ 2019. Uma em cada 4 pessoas assassinadas em SP foi morta pela polícia. Retrieved July 30, 2019, from G1 website: http:// g1.globo.com/sao-paulo/noticia/2016/04/ uma-em-cada-4-pessoas-assassinadasem-sp-foi-morta-pela-policia.html

COLSTEIN, Donna M. 2003. Laughter Out of Place: Race, Class, Violence, and Sexuality in a Rio Shantytown. Berkeley and Los Angeles, California: University of California Press.

HOLSTON, James. 2009. Insurgent Citizenship: Disjunctions of Democracy and Modernity in Brazil. Princeton, New Jersey: Princeton University Press.

KLEIN, Charles H. 2019. "Flipping the City: Space and Subjectivity in the São Paulo Periphery". City \& Society, v.31, n.2: 142163. https://doi.org/10.1111/ciso.12207 
KLEIN, Charles H., Junge, Benjamin \& Mitchell, Sean. 2018. "Naming Brazil's previously poor: The 'new Brazilian middle class' as an economic, political, and experiential category". Economic Anthropology, v.5, n.1: 83-95.

KOWARICK, Lúcio. 2000. Escritos urbanos. São Paulo: Editora 34. 2009. Viver em risco: Sobre

a vulnerabilidade socioeconômica e civil. São Paulo, SP: Editora 34.

KOWARICK, Lúcio \& Frúgoli, Jr., H. 2016. Pluridade Urbana em São Paulo: Vulnerivlidade, Mariganbidade, Ativismos. São Paulo, SP: Editora 34.

LEFEBVRE, Henri. 1991. The production of space (Vol. 142). Oxford: Oxford University Press.

MAGNANI, J. G. C. 1998. Festa no pedaço: Cultura populare lazer na cidade (2nd ed.). São Paulo, SP: Hucitec.

MARQUES, Eduardo. (Ed.). 2014. A metrópole de São Paulo no século XXI: espaços, heterogeniedades de desigualdades. São Paulo: Editora UNESP.

\section{MINISTÉRIO DE FAMIILIA E DOS}

DIREITOS HUMANOS. (n.d.). Juventude Viva [Página]. Retrieved July 31, 2019, from Mulher, da Família e dos Direitos Humanos website:https://www.mdh. gov.br/navegue-por-temas/igualdaderacial/programas/juventude-viva

MOTA, Camila Veras. Bolsonaro é lider mais isolado do populismo de direita hoje, diz pesquisador do extremismo político. BBC News Brasil em São Paulo.Retrieved June 15,m 2020 from https://www.bbc. com/portuguese/internacional-52465613
MOUTINHO, Laura. 2012. “Negociando com a adversidade: Reflexões sobre 'raça', (homos)sexualidade e desigualdade social no Rio de Janeiro". Revista Estudos Feministas, v.14, n.1: 103-116. . 2014. "Diferença e desigualdades negociadas: Raça, sexualidade e gênero em produções acadêmicas recentes". Cadernos Pagu, v.42: 201-248.

PARDUE, Derek. 2010. "Making territorial claims: Brazilian hip hop and the sociogeographical dynamics of periferia". City \& Society, v.22, n.1: 48-71. https://doi. org/10.1111/j.1548-744X.2010.01030.x PERIFERIA SEGUE SANGRANDO! (n.d.). Periferia Segue Sangrando! Retrieved July 31, 2019, from https://www.facebook. com/events/979421362142514/

PETTEGREW, Loyd S. 2017. "An ethnography of humor, ritual and defiance in a cancer care setting". Journal ofOrganizational Ethnography 6(3).

PINHEIRO-MACHADO, Rosana. 2016. "Luzes antropológicas ao obscurantismo: Uma agenda de pesquisa sobre o 'Brasil profundo' em tempos de crise". Revista de Antropologia Da UFSCar, v.8, n.2: 21-28.

PREFEITURA MUNICIPAL DE SÂO PAULO. 2018. População residente por raça/cor, segundo Coordenadoria Regoinal da Saúde (CRS), Supervisão Técnia de Saúde (STS) e Districto Admiminstraitvo (DA), Município de São Paulo, 2010. Retrieveteds ]une 17, 2020 from https:// www.prefeitura.sp.gov.br/cidade/secretarias/ saude/epidemiologia_e_informacao/ geoprocessamento_e_informacoes_ socioambientais/index.php?p=265360

PROJETO FALA GUERREIRA! 2017. Luta, Resistência, Memória em América Latina (Vol. 4). São Paulo, SP: Projeto Fala Guerreira! Mulher e Mídia na Quebrada. 
ARTICLE | Charles Klein, Milena Mateuzi Carmo \& Alessandra Tavares | Between "Us" and "Them":

ROLNIK, Raquel. 2011. "Democracy on the edge: Limits and possibilities in the implementation of an urban reform agenda in Brazil". International Journal of Urban and Regional Research, no-no. https://doi. org/10.1111/j.1468-2427.2010.01036.x

SILVA, Uvanderson Victor da. 2017. Cidadania em negro e branco: Racialização e (luta contra a) violência de Estado no Brasil. Universidade do Estado do Rio de Janeiro.

TAMO VIVO. (n.d.). Tamo Vivo "Home. Retrieved July 31, 2019, from https://www.facebook.com/ Tamo-Vivo-1435266750082059/
TSING, Anna Lowenhaupt. 2011. Friction: An ethnography of global connection. Princeton, New Jersey: Princeton University Press.

ULYSSE, Gina A. 2007. Downtown ladies: Informal commercial importers, a Haitian anthropologist and self-making in Jamaica. Chicago: University of Chicago Press.

VAZ, Sérgio. 2008. Cooperifa: Antropofagia periférica. São Paulo: Aeroplano.

Received on August 5, 2019. Accepted on March 5, 2020. 